\title{
EFFECT OF AGE ON THE INTERRELATIONS BETWEEN GERTAIN BLOOD COMPONENTS AND MILK YIELD DURING EARLY LACTATION PERIOD IN AYRSHIRE COWS INJECTED WITH VITAMIN D ${ }_{3}$ PRIOR TO CALVING
}

\author{
VAPPU Kossila \\ Department of Animal Husbandry, University of Helsinki
}

Received December 4, 1969

Interrelations between the number of trichloracetic acid (TCA) soluble whole blood minerals and the milk yield have been examined by SAArinen (1950), SAARINEn (1953), LANe et al. (1968), and LANe \& CAmpbell (1969).

SAARINEN's (1950) data consisted of 274 arterial blood samples taken from Finnish Ayrshire cows and was characterized by the following mean and range values: stage of lactation 68.6 days (20-252), daily milk yield $20.34 \mathrm{~kg}(10.9-33.6)$, the $\mathrm{Ca} / \mathrm{P}$ of the diet 2.07 (1.07-3.91), daily calcium intake in $\mathrm{g} /$ cow $160.44(67-555)$, daily phosphorus intake in g/cow (33-157), blood calcium (Ca) $6.52 \mathrm{mg} \%(4.01-10.62)$, and blood inorganic phosphorus (P) $4.30 \mathrm{mg} \%$ (2.66-7.38). Partial correlations in his study revealed that the blood $\mathrm{Ca}$ level was positively influenced by the $\mathrm{Ca} / \mathrm{P}$ of the diet and milk yield, while the effects of the daily intakes of calcium and phosphorus were nonsignificant. The blood $\mathrm{P}$ level, in turn, was significantly affected by the daily intake of phosphorus from the diet (positively) and by the milk yield (negatively). The stage of lactation had a nonsignificant effect on the blood Ca and P levels (SAARINEN 1950). A positive simple correlation, 0.12, was found between blood $\mathrm{Ca}$ and P levels (SAARINEN 1953).

In the data of LANE et al. (1968) that was obtained from lactating as well as dry Guernsey cows during all seasons of the year, the blood magnesium $(\mathrm{Mg})$ level correlated positively with the blood Ca level $\left(0.15^{*}\right)$. In lactating cows the blood $\mathrm{Mg}$ was correlated with the level of milk production $\left(0.11^{*}\right)$. LANE \& CAMPBell (1969) obtained also significant correlations for hematocrit $(\mathrm{Hc})$ with blood $\mathrm{P}\left(0.18^{*}\right), \mathrm{Ca}\left(-0.35^{*}\right)$, and $\mathrm{Mg}\left(-0.12^{*}\right)$ levels. Similar but nonsignificant trends were noted in nonlactating cows. Sire, season, pregnancy, age, and stage of lactation were found to affect the blood components by LANE and coworkers; however, the effect of age on the interrelations between the various blood components was not reported in their study. 
The purpose of this study was to investigate the possible effect of age on the interrelations between the serum $\mathrm{Ca}, \mathrm{P}, \mathrm{Mg}$, and blood hemoglobin $(\mathrm{Hb})$ levels and the daily milk yield, during heavy lactation in cows treated with massive doses of vitamin D shortly before calving.

\section{Material and methods}

In 1963, blood samples were drawn from V. jugularis of 38 apparently healthy lactating Ayrshire cows at the Viik Experimental dairy herd during the first 75 days following calving. Approximately one half of the samples were taken during the late indoor feeding period and the other half during the pasture season. Feeding and management of the herd has been recently described by Kossila (1967, p. 32-36). Each cow was injected intramuscularly twice with 5 million I. U. vitamin $\mathrm{D}_{3}$ shortly before calving. The serum $\mathrm{Ca}, \mathrm{P}$, and $\mathrm{Mg}$ levels and blood $\mathrm{Hc}$ and $\mathrm{Hb}$ values were determined as previously described (see KossiLA et al. 1970). The milk yield of each cow was weighed on the day when the blood sample was taken. The live weights and the degree of fatness of the cows were estimated 5 days post partum, and corrections to the live weight in regard to the degree of fatness were made in order to obtain the so-called corrected body weight (ref. Kossila 1967, p. 38). The writer has earlier noted that the milk yield is more closely correlated to the corrected body weight than to the live weight of the cows. Both the absolute (in $\mathrm{kg}$ ) and the relative (in $\mathrm{kg} / 100 \mathrm{~kg}$ corrected body weight) daily milk yields have been considered in this study. Corrections for the fat content of milk were not made, because it was assumed that variations in the milk fat content are probably of minor importance in determining the loss of minerals with milk from the cow's body during lactation.

Statistical calculations were made according to CROXTON \& Cowden (1955).

\section{Results}

The data was divided into two groups, group I comprising 19 cows (67 blood samples) with 1 or 2 calvings, and group II, 19 cows ( 65 blood samples) with more than 2 calvings (mostly 3 to 6 calvings). The average blood $\mathrm{Hc}$ and $\mathrm{Hb}$ values, serum $\mathrm{Ca}, \mathrm{Mg}$, and $\mathrm{P}$ con-

Table 1. Mean and range values of the investigated blood characteristics, level of milk yield, and birth weight of calf in young (I), old (II), and all (I+II) cows.

\begin{tabular}{|c|c|c|c|c|c|}
\hline & \multicolumn{2}{|c|}{ Group I $(N=67)$} & \multicolumn{2}{|c|}{ Group II (N = 65) } & \multirow{2}{*}{$\begin{array}{c}\text { Groups I }+ \text { II }(\mathrm{N}=132) \\
\text { Mean } \pm \mathrm{S}\end{array}$} \\
\hline & Mean $\pm S$ & S Range & Mean $\pm \mathrm{S}$ & Range & \\
\hline Hematocrit value $\%$ & $33.63 \pm 0.12$ & $27.8-40.4$ & $32.87 \pm 0.19$ & $26.2-38.3$ & $33.26 \pm 0.08$ \\
\hline Hemoglobin, $\mathrm{g} / 100 \mathrm{ml}$ blood & $10.20 \pm 0.01$ & $8.2-12.1$ & $9.95 \pm 0.02$ & $7.6-12.3$ & $10.08 \pm 0.01$ \\
\hline Serum calcium, mg \% & $9.69 \pm 0.01$ & $8.5-11.4$ & $9.48 \pm 0.01$ & $7.8-10.9$ & $9.59 \pm 0.00$ \\
\hline " inorg. phosphorus,mg $\%$ & $5.65 \pm 0.02$ & $3.6-8.5$ & $5.31 \pm 0.03$ & $2.5-9.1$ & $5.48 \pm 0.01$ \\
\hline " magnesium, mg $\%$ & $1.78 \pm 0.00$ & $1.0-2.6$ & $1.76 \pm 0.00$ & $1.1-2.6$ & $1.77 \pm 0.00$ \\
\hline $\begin{array}{l}\text { Daily milk yield in } \mathrm{kg} \\
\text { Daily milk yield in } \mathrm{kg} / 100\end{array}$ & $17.51 \pm 0.25$ & $8.1-28.2$ & $24.74 \pm 0.31$ & $11.3-33.6$ & $21.07 \pm 0.24$ \\
\hline kg corrected body weight & $4.05 \pm 0.01$ & $2.0-6.4$ & $5.07 \pm 0.01$ & $2.4-6.7$ & $4.55 \pm 0.01$ \\
\hline Birth wight of the calf, $\mathrm{kg}$ & $33.26 \pm 1.23$ & $25.0-41.0$ & $34.53 \pm 1.97$ & $27.0-48.0$ & $33.89 \pm 0.79$ \\
\hline
\end{tabular}


centrations, absolute and relative daily milk yields, and also the mean birth weights of the calves in group I, group II, and in all cows (I + II) are given in Table 1.

Table 1 indicates that on an average the blood $\mathrm{Hc}$ and $\mathrm{Hb}$ and serum mineral levels of younger cows (group I) were somewhat higher, while the absolute and relative milk yields and the birth weight of the calf were lower compared to corresponding values in older cows (group II). The most pronounced difference between the two age groups was in the milk yield.

Coefficients of simple and partial correlations among blood $\mathrm{Hb}\left(\mathrm{X}_{1}\right)$, serum $\mathrm{Ca}\left(\mathrm{X}_{2}\right)$, $\mathrm{Mg}\left(\mathrm{X}_{3}\right), \mathrm{P}\left(\mathrm{X}_{4}\right)$, and absolute daily milk yield $\left(\mathrm{X}_{5}\right)$ or relative daily milk yield $\left(\mathrm{X}_{5 \mathrm{a}}\right)$ were calculated separately for group I, group II, as well as for all cows (I + II). These results have been summarized in Table 2 .

Since the preliminary calculations had revealed a very close correlation between the Hc and $\mathrm{Hb}$ values in group I (0.83) as well as in group II $(0.89)$, of these two blood characteristics, only the $\mathrm{Hb}$ value was included as a variable in the further statistical calculations.

The results presented in Table 2 indicate that the significance of the simple and corresponding partial correlations turned out to be very much alike.

In y o u n g e r c o w s, significant partial correlations were obtained for $\mathrm{Hb}$ with $\mathrm{Mg}$ $\left(0.29^{*}\right)$ and the milk yield $\left(-0.28^{*}\right)$, and for $\mathrm{Ca}$ with the milk yield $\left(0.54^{* * *}\right)$. Positive trends were found for $\mathrm{Hb}$ with $\mathrm{Ca}(0.18)$, and negative trends for $\mathrm{Ca}$ with $\mathrm{Mg}(-0.13)$, and for $\mathrm{P}$ with the milk yield $(-0.15)$.

In o l d e $\mathrm{r}$ c o w s, significant partial correlations were obtained for $\mathrm{Hb}$ with the milk yield $\left(-0.42^{* * *}\right)$, and for $\mathrm{Mg}$ with $\mathrm{P}\left(0.25^{*}\right)$. A positive trend was found for $\mathrm{Hb}$ with $\mathrm{P}$ (0.14), and negative trends for $\mathrm{Mg}$ with $\mathrm{Hb}(-0.12)$ and the milk yield $(-0.24)$, and for Ca with the milk yield $(-0.11)$.

In a 11 c o w s, a significant partial correlation was found for $\mathrm{Hb}$ with the milk yield $\left(-0.31^{* * *}\right)$. Positive trends were found for $\mathrm{Mg}$ with $\mathrm{Hb}(0.11)$ and $\mathrm{P}(0.14)$. Negative trends were found for $\mathrm{Mg}$ with $\mathrm{Ca}(-0.14)$ and the milk yield $(-0.10)$, and for $\mathrm{P}$ with the milk yield $(-0.12)$.

\section{Discussion}

In this study age had a significant effect on certain correlations between blood (serum) components and milk yield. Furthermore, the level of significance of the correlations remained nearly the same irrespective of whether the absolute or relative milk yield was used as one the variables in the statistical calculations, and the significance of the partial correlations was of the same order as that of the corresponding simple correlations (Table 2).

The correlation trends found in this study differ in several respects from those presented by SaArinen (1950), SaArinen (1953), Lane et al. (1968), and Lane \& Campbell (1969) apparently as a result of the differences in the methods and materials. The cows of this study received massive doses of vitamin $\mathrm{D}$ prior to calving, which treatment aids in the attaining of normal serum Ca and P levels more rapidly after calving (ref. KossiLA et al. 1970). Apparently vitamin D was not used for the said purpose in the studies of Lane \& coworkers and Saarinen. On the other hand, it is not known exactly how long the effect of vitamin D, when administered shortly before calving, persists during the ascending phase of lactation.

In this study, special attention is paid to the correlation found between the serum $\mathrm{Ca}$ level and the milk yield, which was highly significant in younger cows $\left(0.54^{* * *}\right)$ but non- 
Table 2. Simple and partial correlations among blood hemoglobin $\left(\mathrm{X}_{1}\right)$, serum calcium $\left(\mathrm{X}_{2}\right)$, magnesium $\left(\mathrm{X}_{3}\right)$, inorganic phosphorus $\left(\mathrm{X}_{4}\right)$, and daily milk yield in $\mathrm{kg}\left(\mathrm{X}_{5}\right)$ or daily milk yield in $\mathrm{kg}$ per $100 \mathrm{~kg}$ body weight corrected for fatness $\left(\mathrm{X}_{\mathrm{sa}}\right)$ in young $(\mathrm{I})$, old $(\mathrm{II})$, and all $(\mathrm{I}+\mathrm{II})$ cows.

\begin{tabular}{|c|c|c|c|c|}
\hline & & $(\mathbf{N}=67)$ & $\begin{array}{c}\mathrm{II} \\
(\mathrm{N}=65)\end{array}$ & $\begin{array}{c}\mathrm{I}+\mathrm{II} \\
(\mathrm{N}=132)\end{array}$ \\
\hline $\mathrm{Hb} . \mathrm{Ca}$ & $\begin{array}{l}r_{12} \\
r_{12 \cdot 345} \\
r_{12 \cdot 345 a}\end{array}$ & $\begin{array}{r}-0.01 \\
0.18 \\
0.15\end{array}$ & $\begin{array}{r}-0.02 \\
-0.05 \\
-0.06\end{array}$ & $\begin{array}{l}-0.02 \\
0.01 \\
0.02\end{array}$ \\
\hline Hb.Mg & $\begin{array}{l}\mathrm{r}_{13} \\
\mathrm{r}_{13 \cdot 245} \\
\mathrm{r}_{13 \cdot 245 a}\end{array}$ & $\begin{array}{l}0.31^{* *} \\
0.29^{*} \\
0.28^{*}\end{array}$ & $\begin{array}{r}0.02 \\
-0.12 \\
-0.10\end{array}$ & $\begin{array}{l}0.17 \\
0.11 \\
0.10\end{array}$ \\
\hline Hb.P & $\begin{array}{l}\mathrm{r}_{14} \\
\mathrm{r}_{14 \cdot 235} \\
\mathrm{r}_{14 \cdot 235 a}\end{array}$ & $\begin{array}{l}0.09 \\
0.02 \\
0.02\end{array}$ & $\begin{array}{l}0.13 \\
0.14 \\
0.12\end{array}$ & $\begin{array}{l}0.12 \\
0.06 \\
0.05\end{array}$ \\
\hline Hb.Milk & $\begin{array}{l}r_{15} \\
r_{15 a} \\
r_{15 \cdot 234} \\
r_{15 a \cdot 234}\end{array}$ & $\begin{array}{l}-0.27^{*} \\
-0.29^{*} \\
-0.28^{*} \\
-0.27^{*}\end{array}$ & $\begin{array}{r}-0.41^{* * *} \\
-0.42^{* * *} \\
-0.42^{* * *} \\
-0.43^{* * *}\end{array}$ & $\begin{array}{r}-0.34^{* * *} \\
-0.37 * * * \\
-0.31 * * * \\
-0.34 * * *\end{array}$ \\
\hline Ca.Mg & $\begin{array}{l}\mathrm{r}_{23} \\
\mathrm{r}_{23 \cdot 145} \\
\mathrm{r}_{23 \cdot 145 a}\end{array}$ & $\begin{array}{r}-0.16 \\
-0.13 \\
-0.12\end{array}$ & $\begin{array}{r}-0.15 \\
-0.15 \\
-0.14\end{array}$ & $\begin{array}{r}-0.14 \\
-0.14 \\
-0.14\end{array}$ \\
\hline Ca.P & $\begin{array}{l}r_{24} \\
r_{24 \cdot 135} \\
r_{24} \cdot 135 a\end{array}$ & $\begin{array}{l}0.00 \\
0.09 \\
0.07\end{array}$ & $\begin{array}{r}-0.11 \\
-0.07 \\
-0.08\end{array}$ & $\begin{array}{r}-0.04 \\
-0.01 \\
-0.01\end{array}$ \\
\hline Ca.Milk & $\begin{array}{l}\mathrm{r}_{25} \\
\mathrm{r}_{25 \mathrm{a}} \\
\mathrm{r}_{25 \cdot 134} \\
\mathrm{r}_{25 a \cdot 134}\end{array}$ & $\begin{array}{l}0.53 * * * \\
0.42 * * * \\
0.54 * * * \\
0.42^{* * *}\end{array}$ & $\begin{array}{r}-0.06 \\
-0.08 \\
-0.11 \\
-0.12\end{array}$ & $\begin{array}{l}0.03 \\
0.04 \\
0.01 \\
0.02\end{array}$ \\
\hline Mg.P & $\begin{array}{l}\mathrm{r}_{34} \\
\mathrm{r}_{34 \cdot 125} \\
\mathrm{r}_{34 \cdot 125 a}\end{array}$ & $\begin{array}{l}0.07 \\
0.05 \\
0.04\end{array}$ & $\begin{array}{l}0.26^{*} \\
0.25^{*} \\
0.25^{*}\end{array}$ & $\begin{array}{l}0.17 \\
0.14 \\
0.14\end{array}$ \\
\hline Mg.Milk & $\begin{array}{l}r_{35} \\
r_{35 a} \\
r_{35 \cdot 124} \\
r_{35 a \cdot 124}\end{array}$ & $\begin{array}{l}-0.19 \\
-0.21 \\
-0.02 \\
-0.07\end{array}$ & $\begin{array}{l}-0.21 \\
-0.16 \\
-0.24 \\
-0.18\end{array}$ & $\begin{array}{l}-0.17 \\
-0.18 * \\
-0.10 \\
-0.11\end{array}$ \\
\hline P.Milk & $\begin{array}{l}r_{45} \\
r_{45 a} \\
r_{45 \cdot 123} \\
r_{45 a \cdot 123}\end{array}$ & $\begin{array}{r}-0.14 \\
-0.16 \\
-0.15 \\
-0.15\end{array}$ & $\begin{array}{r}-0.07 \\
-0.09 \\
0.03 \\
-0.01\end{array}$ & $\begin{array}{l}-0.17 \\
-0.17 \\
-0.12 \\
-0.11\end{array}$ \\
\hline
\end{tabular}

significant in older cows $(-0.11)$. It seems improbable that increasing the serum Ca level stimulates the secretion of milk in young cows, even though a low serum Ca level may be an inhibitory factor for milk secretion (ref. RAMBERG et al. 1967). Other explanations are possible.

The $\mathrm{Ca} / \mathrm{P}$ of milk is usually about $1.2: 1$, while calcium and phosphorus are mobilized from bone in a higher ratio, i.e. in a ratio of $2: 1$. It has been noted that calcium mobilization 
is faster in young and lactating than in old or nonlactating cows (HANSARD et al. 1954, PAPPENHAgen 1959). Hence it is possible that in young cows, as a result of active bone mineral mobilization, a rising surplus of calcium in respect of phosphorus, has remained in the circulation at the same time when the milk yield, and in consequence, also the lactational requirements for $\mathrm{Ca}$ and $\mathrm{P}$ have incresed, these phenomena explaining the significant positive correlation found for serum Ca with the milk yield and the negative correlation found for serum $\mathrm{P}$ with the milk yield respectively.

On the other hand, in older cows, whose milk production has been significantly higher than that of younger cows (Table 1), the dietary minerals are apparently quantitatively more important than the bone minerals in maintaining the serum $\mathrm{Ca}$ and $\mathrm{P}$ levels adequate during the ascending phase of lactation. Moreover, Lomba et al. (1968) have noted that the calcium excreted in faeces falls when the Ca requirements for milk are growing. The negative trend found for serum $\mathrm{Ca}$ with the milk yield (partial correlation -0.12 ) in older cows (Table 2) may be taken to indicate that the rate of utilization of dietary and bone minerals for the maintenance of the serum Ca level with an increasing milk yield has been slightly below optimal.

Practically no correlation was found for serum $\mathrm{P}$ with the milk yield in older cows. LомвA et al. (1969) noted that the utilization of phosphorus from the diet is highly variable, being, however, markedly more efficient in lactating than in dry cows. They also found a significant positive correlation between the amounts of phosphorus secreted in milk and urine. These observations may explain the phenomenon noted in this study that the milk yield, as a whole, had very little effect on the serum P level.

The serum Mg level was not found to be affected by the milk yield in young cows (Table 2 ). However, a nearly significant negative partial correlation was found for $\mathrm{Mg}$ with the milk yield $(-0.24)$ in older cows, in spite of the fact that the amount of $\mathrm{Mg}$ secreted in milk is not large. BAKKER (1960) reported lower serum Mg levels in high-yielders than in lowyielders. Rook \& Storry (1963) and O'Kelley \& Fontenot (1968) have demonstrated that the serum $\mathrm{Mg}$ level is positively influenced by the intake of $\mathrm{Mg}$ from the diet of the cows. Probably either the intake or the availability of dietary $\mathrm{Mg}$ in the case of older cows has not been quite high enough for the maintenance of the $\mathrm{Mg}$ level in serum with an increasing milk yield. According to LomBa et al. (1968), even cows which produced $10-20 \mathrm{~kg}$ milk daily (compare Table 1 group II) had generally a negative $\mathrm{Mg}$ balance. They also found a significant positive correlation between the starch intake and $\mathrm{Mg}$ in urine $\left(0.53^{*}\right)$ in lactating cows, while the correlation between $\mathrm{Mg}$ in milk and $\mathrm{Mg}$ in urine was nonsignificant. It seems thus that the composition of the diet (contents of starch, $\mathrm{Mg}$, and a number of other substances) is of greater importance than the level of milk production as far as the serum $\mathrm{Mg}$ level is concerned.

A significant positive partial correlation was found for $\mathrm{Mg}$ with $\mathrm{P}$ in older cows $\left(0.25^{*}\right)$ but practically no correlation respectively in younger cows $(0.05)$. This phenomenon seems to be hard to explain. However, in the previous study (Kossila et al. 1970) simultaneously rising $\mathrm{Mg}$ and $\mathrm{P}$ levels were found in a few ketotic cows, and it is known that older cows are more apt to develop this disturbance than younger ones.

In young, old, and all cows, significant negative correlations were found for $\mathrm{Hb}$ with the milk yield (Table 2). This correlation was more significant in older cows which produced more milk compared to younger cows (Table 1). This phenomenon is believed to be mainly 
due to the greater increase of the plasma than the red cell volume during the ascending phase of lactation. This assumption is supported by the results of several studies. Sмттн \& KESLER (1969) found higher Hb values on Day 1 post partum than 5 weeks post p.; the trends in Hc were similar. Turner \& Herman (1931) found larger blood volumes and Dale et al. (1957) in addition also lower Hc values in lactating than in dry cows. High-yielders had larger blood volumes than low-yielders in the studies of Bogdanov (1961) and Zaboeva (1963). In Polish Red cows, the Hb was negatively correlated with the maximal daily milk yield (Zieba 1964). On the other hand, PAtterson et al. (1960) failed to obtain significant correlations between $\mathrm{Hb}$ and the lactational ability in Holstein and Jersey cows; LANE \& Campbell (1969) found no correlation for Hc with the milk yield in Guernsey cows, while Bogdanov (1961) reported higher $\mathrm{Hb}$ values for high-yielders in Black Pied cattle. FisHer (1962), in turn, found higher Hc values in lactating than in dry cows. However, in the dairy herd of the Viik Experimental farm, dry pregnant cows had higher $\mathrm{Hc}$ and $\mathrm{Hb}$ values than lactating nonpregnant ones as can be seen from the following compilation:

\begin{tabular}{|c|c|c|}
\hline & dry pregnant & lactating nonpregnant \\
\hline & $\mathrm{Hb} \mathrm{Hc}$ & $\mathrm{Hb} \quad \mathrm{Hc}$ \\
\hline group I & $\begin{array}{lll}11 & 10.98 & 34.88\end{array}$ & $\begin{array}{lll}67 & 10.20 & 33.63\end{array}$ \\
\hline group II & $\begin{array}{llll}9 & 11.12 & 35.33\end{array}$ & $\begin{array}{lll}65 & 9.95 & 32.87\end{array}$ \\
\hline
\end{tabular}

The cows in the said herd have received mineral salt mixture containing, among others, iron, copper and cobalt (see Kossila 1967, p. 34) which elements are known to be essential for the formation of $\mathrm{Hb}$. Hence, the negative correlation found for the $\mathrm{Hb}$ value with the level of the milk yield (Table 2) is not readily explainable on the basis of a possible shortage of these hemopoietic substances in the diet particularly since the quantity of these elements secreted with the milk is small.

\section{Su m mary}

Altogether 132 blood samples were drawn from V. jugularis of 38 apparently healthy lactating Ayrshire cows during the first 75 days following parturition. Each cow had been injected twice with 5 million I. U. of vitamin $\mathrm{D}_{3}$ shortly before calving. The cows were divided into two groups, I comprising 19 cows with 1 or 2 calvings and II 19 cows with more than 2 calvings. The blood hemoglobin $(\mathrm{Hb})$, and hematocrit $(\mathrm{Hc})$ values, and the amounts of calcium $(\mathrm{Ca})$, inorganic phosphorus $(\mathrm{P})$, and magnesium $(\mathrm{Mg})$ in serum were determined and coefficients of correlation between the blood components and the level of the daily milk yield were calculated. The following significant partial correlations were obtained: in group I, for $\mathrm{Hb}$ with $\mathrm{Mg}\left(0.29^{*}\right)$ and milk yield $\left(-0.28^{*}\right)$, and for $\mathrm{Ca}$ with milk yield $\left(0.54^{* *}\right)$; in group II, for $\mathrm{Hb}$ with milk yield $\left(-0.42^{* * *}\right)$, and for $\mathrm{Mg}$ with $\mathrm{P}(0.25 *)$; in groups $\mathrm{I}+\mathrm{II}$, for $\mathrm{Hb}$ with milk yield $\left(-0.31^{* * *}\right)$. The significance of the simple and corresponding partial correlations was very similar, and it did not make much difference whether the absolute instead of the relative daily milk yield was used as a variable in the calculations. The results are discussed in detail. 


\section{REFERENCES}

BAKKer, Y. T. 1960. The serum magnesium content of dairy cattle under different conditions. Landbouwk. Tijdschr. 72:619-634.

Bogdanov, L. V. 1961. The blood volume and haemoglobin indices in relation to level of production and type of conformation in dairy cows. Izv. Timir. sel'skoh. Akad. 6: 160-71.

Croxton, F. E. \& Cowden, D. J. 1955. Applied general statistics. 2nd ed. XVI+843 pp. Chapt. 21. London.

Dale, H. E., Burge, G. J. \& Brody, S. 1957. The effect of environmental temperature on blood volume and the antipyrine space in dairy cattle. Am. J. Vet. Res. 18: 97-100.

Fishzr, E. W. 1962. Observations on the bovine haematocrit. Brit. Vet. J. 118: 513-21.

Hansard, S. L., Comar, C. L. \& Plumlee, M. P. 1954. The effects of age upon calcium utilization and maintenance requirements in the bovine. J. Anim. Sci. 13: 25.

KossizA, V. 1967. On the weight and basic structural components of the thyroid in dairy cattle. Acta Agr. Fenn. 109.2 pp. 115.

-”- Niemel. A, P. \& Koskenkorva, E. 1970. Variations of serum calcium, inorganic phosphorus and magnesium levels due to stage of lactation, season, and age in the Ayrshire cows injected with vitamin D prior to calving. J. Sci. Agr. Soc. Finl. (in press).

LAne, A. G. \& Campbel. J. R. 1969. Relationship of hematocrit values to selected physiological conditions in dairy cattle. J. Anim. Sci. 28: 508-511.

- - - - - — \& KRAUSE, G. F. 1968. Blood mineral composition in ruminants. Ibid. 27: 766-770.

Lomba, F., Paquay, R., Bienfet, V. \& Lousse, A. 1968. Statistical research on the fate of dietary mineral elements in dry and lactating cows. II. Magnesium. J. Agric. Sci., Camb. 71: 181—88.

- - - - - - - 1969. Statistical research on the fate of dietary mineral elements in dry and lactating cows. III. Phosphorus. Ibid. 73: 215-222.

O'Kelley, R. E. \& Fontenot, J. P. 1968. Dietary magnesium levels for lactating beef cows. J. Anim. Sci. 27: 296.

Pappenhagen, A. R. 1959. Parathyroid hormone and parturient paresis in dairy cattle. Diss. Abstr. 20: 1566.

Paquay, R., Lomba, F., Lousse, A. \& Bienfet, V. 1968. Statistical research on the fate of dietary minera elements in dry and lactating cows. I. Calcium. J. Agric. Sci., Camb. 71: 173-80.

Patterson, T. B., Shrode, R. R., Kunkel, H. O., Leighton, R. E. \& Rupel, I. W. 1960. Variations in certain blood components of Holstein and Jersey cows and their relationship to daily range in rectal temperature and to milk and butterfat production. J. Dairy Sci. 43: 1263.

Rambero, C. F. Jr., Mayer, G. P., Kronfeld, D. S., Aurbach, G. D., Sherwood, L. M. \& Potts, J. T. Jr. 1967. Plasma calcium and parathyroid hormone responses to EDTA infusion in the cow. Am. J. Physiol. 213: 878-82.

SAarinen, P. 1950. A statistical study of the effect of excessive feeding of calcium and phosphorus supple ments on the blood calcium and phosphorus of dairy cows. J. Sci. Agr. Soc. Finl. 22: 122-130.

- - 1953. A statistical study of the interrelations between certain mineral constituents of the blood of dairy cows. Ibid. 25: 9-15.

Smtrh, J. W. \& Kesler, E. M. 1969. Blood protein changes during the lactation cycle of Holstein cows. J. Dairy Sci. 52: 279.

Storry, J. E. \& Rook, J. A. K. 1963. Magnesium metabolism in the dairy cow. V. Experimental observations with a purified diet low in Mg. J. Agric. Sci. 61: 167-171.

Turner, C. W. \& Herman, H. A. 1931. A determination of the blood and plasma volume of dairy cattle. Mo. Agr. Exp. Sta. Res. Bul. No. 159.

Zaboeva, I. P. 1963. Changes in the volume of plasma and blood in Black Pied cows with age and in the course of lactation. Dokl.mosk. sel.'-khoz. Akad. K. A. Timir. (Zoot.) 85: 129-32.

ZIEBA, J. 1964. Correlation between some blood indices in Polish Red heifers and their milk yield in the first lactation. Annls Univ. Mariae-Curie Sklodowska 19 E: 483-98. 


\title{
IÄN VAIKUTUS VEREN ERÄIDEN KIVENNÄISKOMPONENTTIEN JA PÄIVITTÄISEN MAITOTUOTOKSEN VÄLISIIN VUOROSUHTEISIIN LYPSYLEHMILLÄ
}

\author{
VAPPU Kossil.A
}

\section{Helsingin yliopiston kotieläintieteen laitos}

Yhteensä 132 verinäytettä kerättiin 38 lehmästä laktaatiokauden 0 . — 75. päivinä. Ennen poikimista lehmiin oli injektoitu $2 \times 5$ milj. ky. $D_{3}$-vitamiinia. 19 lehmistä oli poikinut $1-2$ kertaa $($ ryhmä I) ja 19 yli 2 kertaa (enimmäkseen 3-6 kertaa) (ryhmä II). Verinäytteistä määritettiin hematokriitti (Hc) ja hemoglobiini $(\mathrm{Hb})$ arvot sekä seerumin kalsium $(\mathrm{Ca})$, epäorgaaninen fosfori $(\mathrm{P})$ ja magnesium $(\mathrm{Mg})$. Päivittäin tuotettu maitomäärä punnittiin verenottopäivinä. Tutkimusajanjaksona saatiin seuraavat keskiarvot ryhmille I ja II: Hc 33.63 ja $32.87 \%$; Hb 10.20 ja 9.95 g/100 ml verta; Ca 9.69 ja 9.48 mg \% ; P 5.65 ja $5.31 \mathrm{mg} \%$, Mg 1.78 ja 1.76 mg \%; päivittäinen maitotuotos 17.51 ja 24.74 kg; suhteellinen maitotuotos päivässä (kg maitoa/100 kg lihavuuskunto korjattuna elopainoa) 4.05 ja $5.07 \mathrm{~kg}$ (Taulukko 1).

Veren $\mathrm{Hc}$ ja $\mathrm{Hb}$ tasojen väliset vuorosuhteet olivat kummallakin ryhmällä erittäin merkittävät (I 0.83 ja II 0.89) ja tästä syystä osittaisvuorosuhteita laskettaessa Hc arvoa ei sisällytetty muuttujien joukkoon.

Ikä vaikutti selvästi eräisiin vuorosuhteisiin (Taulukko 2). Ryhmässä I ilmeni seuraavien muuttujien välillä merkittävät osittaisvuorosuhteet: Hb.Mg $0.28 *$, Hb.maitotuotos $-0.28^{*}$, Hb.suhteellinen maitotuotos $-0.27 *$, Ca. maitotuotos $0.54 * * *$ ja Ca.suhteellinen maitotuotos $0.42 * * *$. Ryhmälle II saatiin seuraavat merkittävät osittaisvuorosuhtet: Hb.maitotuotos $-0.42 * * *$, Hb.suhteellinen maitotuotos $-0.43^{* * *}$, ja Mg.P 0.25* (Taulukko 2). Yksinkertaisten ja vastaavien osittaisvuorosuhteiden merkittävyys oli yleensä samaa suuruusluokkaa ja tuloksiin ei maitotuotoksen laskentatapa (päivittäinen tuotos kiloina tai suhteellinen tuotos) näyttänyt sanottavasti vaikuttavan. Vuorosuhteisiin mahdollisesti vaikuttaneita tekijöitä on tarkastettu yksityiskohtaisesti. 